\title{
PEDAGONAL
}

Jurnal IImiah Pendidikan

http://journal.unpak.ac.id/index.php/pedagonal

\section{PERILAKU HIDUP BERSIH DAN SEHAT PEDAGANG MAKANAN DI KAWASAN UNIVERSITAS PAKUAN}

\author{
Rita Istiana a, ${ }^{a}$, Muhammad Taufik Awaludina \\ aProgram Studi Pendidikan Biologi Fakultas Keguruan dan IImu Pendidikan, Universitas Pakuan \\ *korespondensi: ritaistiana12@gmail.com
}

\begin{abstract}
Abstrak
Penelitian ini bertujuan untuk mengkaji dan menganalisis korelasi antara Tingkat Pendidikan, Pendapatan dengan Perilaku Hidup Bersih dan Sehat Para Pedagang Makanan di Kawasan Universitas Pakuan. Penelitian dilakukan pada para pedagang makanan di sekitar kawasan Universitas Pakuan pada Tahun 2016 dengan jumlah sampel 40 pedagang yang diambil secara sampling purposif. Pengambilan data yang digunakan dengan membagikan kuesioner dan melakukan observasi langsung juga wawancara. Kalibrasi instrument dilakukan dengan menggunakan judgment ahli. Teknik analisis data menggunakan uji statistik korelasi dan regresi linier, pengujian hipotesis dilakukan pada taraf signifikan 0,01 dengan bantuan software SPSS 20. Hasil penelitian menunjukkan adanya: 1) korelasi positif dan signifikan antara pendidikan dengan perilaku hidup bersih dan sehat para pedagang makanan di kawasan Unpak dengan koefisien korelasi $\left(r_{\mathrm{y} 1}\right)$ sebesar 0,778 , dan koefisien determinasi $\left(r^{2} y 1\right)$ sebesar 0,606 dengan persamaan regresinya $\hat{Y}=0,222+$ $0,746 X_{1}$. 2) korelasi positif dan signifikan antara pendapatan dengan perilaku hidup bersih dan sehat para pedagang makanan di kawasan Unpak dengan koefisien korelasi $\left(r_{y 2}\right)$ sebesar 0,672 dan koefisien determinasi $\left(r^{2}{ }^{2}\right)$ sebesar 0,032 dengan persamaan regresinya $\hat{Y}=102,599+0,154 X_{2}$. Kesimpulan dari hasil penelitian ini adalah bahwa perilaku hidup bersih dan sehat dapat ditingkatkan melalui peningkatan pendidikan dan pendapatan para pedagang makanan di kawasan Universitas Pakuan Bogor.
\end{abstract}

Kata Kunci : Pendidikan, Pendapatan, Perilaku Hidup Bersih dan Sehat

\begin{abstract}
The purpose of this study is to assess and analyze the correlation between education level, income with Behavior Clean and Healthy Food Region Traders Pakuan University. The study was conducted at the food vendors in the surrounding area Pakuan University in 2016 with a sample of 40 vendors were taken by purposive sampling. Retrieval of the data used by distributing questionnaires and direct observation interviews. Instrument calibration is done using expert judgment. Data were analyzed using statistical test of correlation and linear regression, hypothesis testing was done on a significant level of 0.01 with SPSS 20. Results showed that: 1) positive and significant correlation between education and behavior of clean and healthy food traders in the region Unpak with correlation coefficients (ry1) of 0.778, and the coefficient of determination (r2y1) of 0.606 with a regression equation $Y=0.222+0.746 \times 1$. 2) positive and significant correlation between income with hygienic behavior and healthy food traders in the region Unpak with correlation coefficients (ry2) of 0.672 and a coefficient of determination (r2y2) amounted to 0.032 with the regression equation $Y=102.599+0.154 X 2$. The conclusion of this study is that the behavior of clean and healthy living can be improved by improving education and income food traders in the region Pakuan University Bogor.
\end{abstract}

Keywords: Education, Income, Clean and Healthy Behavior 


\section{PENDAHULUAN}

Kesehatan masyarakat dipengaruhi oleh lingkungan yang bersih. Lingkungan yang tidak bersih dapat menyebabkan timbulnya berbagai macam penyakit. Banyak faktor yang mempengaruhi kesehatan di Indonesia diantaranya urbanisasi penduduk, tingkat pendidikan, lingkungan, tempat pembuangan sampah dan limbah, petugas kesehatan, pelayanan kesehatan dan budaya masyarakat. Masalah kesehatan yang dipengaruhi oleh tingkat pendidikan menyebabkan rendahnya pemahaman atau pengetahuan tentang hidup sehat sehingga berpengaruh dengan perilaku masyarakat yang kurang menghargai kesehatan. Proses terbentuknya perilaku yang diawali dengan pengetahuan membutuhkan pemahaman yang diperoleh dari pendidikan kesehatan. Pendidikan kesehatan merupakan kegiatan menyampaikan pesan kepada masyarakat untuk berperilaku sehat. Faktor kedua adalah lingkungan, kesehatan lingkungan yang optimum dapat berpengaruh positif terhadap terbentuknya kesehatan masyarakat. Lingkungan merupakan faktor yang berpengaruh karena manusia tinggal didalam suatu lingkungan. Lingkungan yang buruk sangat berpengaruh terhadap status kesehatan.

Masalah kesehatan lingkungan terdiri dari kesehatan pemukiman, penyediaan air bersih, pengelolaan limbah dan sampah. Lingkungan pemukiman khususnya rumah tinggal merupakan salah satu kebutuhan dasar bagi kehidupan manusia. Buruknya sanitasi dan keterbatasan air bersih dapat menimbulkan berbagai masalah kesehatan yaitu munculnya berbagai macam penyakit. Selama ini upaya yang dilakukan masyarakat untuk mengatasi masalah penyakit, masih banyak berorientasi pada penyembuhan penyakit. Upaya ini dirasa kurang efektif karena banyak mengeluarkan biaya. Sedangkan upaya yang paling efektif dalam mengatasi masalah kesehatan dengan memelihara dan meningkatkan kesehatan dengan berperilaku bersih dan sehat.

Penerapan Perilaku Hidup Bersih dan Sehat (PHBS) di Kota Bogor PHBS menjadi salah satu kriteria pentahapan Kelurahan Siaga Aktif. Pemberdayaan masyarakat untuk ber PHBS harus dimulai dari rumah tangga, karena rumah tangga yang ber PHBS merupakan aset dan modal pembangunan kesehatan di masa depan yang perlu dijaga, dilindungi dan ditingkatkan kesehatannya. Beberapa anggota rumah tangga mempunyai masa rawan terkena penyakit menular dan penyakit tidak menular, oleh karena itu untuk mencegah penyakit tersebut, anggota rumah tangga perlu diberdayakan untuk melaksanakan PHBS. PHBS di rumah tangga diarahkan untuk memberdayakan setiap keluarga atau anggota rumah tangga agar tahu, mau, dan mampu menolong diri sendiri di bidang kesehatan dengan mengupayakan lingkungan yang sehat, mencegah dan menanggulangi masalah-masalah kesehatan yang dihadapi, memanfaatkan sarana pelayanan kesehatan yang ada, serta berperan aktif mewujudkan kesehatan masyarakatnya dan mengembangkan upaya kesehatan bersumberdaya masyarakat. Ada 10 (sepuluh) indikator PHBS rumah tangga yang harus dilaksanakan oleh seluruh anggota rumah tangga yaitu : 1) Persalinan oleh tenaga kesehatan 2) Bayi diberi ASI Ekslusif 3) Balita ditimbang setiap bulan 4) Menggunakan air bersih 5) Cuci tangan pakai air bersih dan sabun 6) Menggunakan jamban sehat 7) Memberantas jentik nyamuk di rumah 8) Makan sayur dan buah setiap hari 9) Melakukan aktifitas fisik setiap hari 10) Tidak merokok di dalam rumah Untuk mewujudkan rumah tangga ber PHBS, upaya-upaya yang telah dilakukan diantaranya penyuluhan kesehatan baik secara langsung ke masyarakat, melalui seminar atau talkshow melalui media/radio, sosialisasi melalui media (poster, leaflet, stiker,banner,dll), kampanye kesehatan, mobile wawar, demonstrasi cuci tangan pakai sabun, gerakan serentak PSN dengan $3 \mathrm{M}$ Plus, lomba-lomba penerapan PHBS di wilayah, dll. Berdasarkan hasil survei PHBS rumah tangga di Kota Bogor tahun 2014 yang telah dilakukan oleh kader kesehatan di masing-masing wilayah, diperoleh hasil capaian rumah tangga ber PHBS Kota Bogor adalah 62,1\%. Hasil tersebut masih jauh dari target yaitu 85\% rumah tangga ber PHBS tahun 2014. Perlu dilakukan berbagai terobosan dan inovasi dengan bersumberdaya masyarakat, swasta serta didukung oleh Pemerintah untuk meningkatkan pengetahuan, sikap dan perilaku masyarakat dalam ber PHBS. ( Kep.DinKes Kota Bogor, 2014 ).

Berdasarkan hasil survei pendahuluan yang dilakukan pada pedagang makanan disekitar Universitas Pakuan Bogor ditemukan bahwa pedagang makanan belum berperilaku hidup bersih dan sehat. Hal ini dikarenakan ditempat kerja pedagang makanan belum menjaga kebersihan peralatan makan dan minum, masih terdapat kualitas fisik sumber air yang tidak memenuhi syarat, dan belum semua mempunyai saluran air kotor, tidak tersedianya tempat sampah, dan tidak tertutupi dengan baik makanan dan minumannya.

Peran penyedia makanan dan minuman seperti pedagang makanan di sekitar Universitas Pakuan ikut berperan dalam keberhasilan program pengendalian penyakit menular. Namun pedangang makanan sangat terbatas kemampuannya untuk menjamin dagangannya tetap aman, sehat, dan bergizi untuk dikonsumsi, sehingga penulis tertarik untuk melakukan penelitian tentang korelasi pendidikan, pendapatan dan perilaku hidup bersih dan sehat para pedagang makanan di sekitar Universitas Pakuan Bogor. 
Tingkat pendidikan berkorelasi dengan kemampuan menerima informasi kesehatan dari media massa dan petugas kesehatan. Banyak kasus kesakitan dan kematian masyarakat diakibatkan rendahnya tingkat pendidikan penduduk. Suatu laporan dari negara bagian Kerala di India Utara menyatakan bahwa status kesehatan disana sangat baik, jauh diatas rata-rata status kesehatan nasional. Setelah ditelusuri ternyata tingkat pendidikan kaum wanitanya sangat tinggi diatas kaum pria (Widoyono, 2008).

Masyarakat yang memiliki tingkat pendidikan lebih tinggi berorientasi pada tindakan preventif, mengetahui lebih banyak tentang masalah kesehatan dan memiliki status kesehatan yang lebih baik. Pada perempuan, semakin tinggi tingkat pendidikan, semakin rendah angka kematian bayi dan kematian ibu (Widyastuti, 2005). Tingkat pendidikan sangat berpengaruh terhadap perubahan sikap menuju perilaku hidup sehat. Tingkat pendidikan yang tinggi akan memudahkan seseorang atau masyarakat memperoleh dan mencerna informasi untuk kemudian menentukan pilihan dalam pelayanan kesehatan dan menerapkan hidup sehat. Tingkat pendidikan, khususnya tingkat pendidikan wanita mempengaruhi derajat kesehatan (Depkes RI, 1999).

Bila ditinjau dari faktor sosial ekonomi, pendapatan merupakan salah satu faktor yang mempengaruhi tingkat wawasan masyarakat mengenai sanitasi, lingkungan dan perumahan. Kemampuan anggaran rumah tangga juga mempengaruhi kecepatan untuk meminta pertolongan apabila anggota keluarganya sakit (Widoyono, 2008). Menurut Grossman dalam Murti (2005) terdapat perbedaan antara upah minimum dengan pendapatan, jika pendapatan adalah uang yang diterima tanpa bekerja permintaan untuk modal kesehatan mungkin lebih kecil karena pendapatan tidak secara langsung mengurangi status kesehatan. Pendapatan yang diterima tidak secara langsung berkorelasi dalam memberi keuntungan atau kerugian atau memberi manfaat kesehatan. Akibatnya, tingkat optimalisasi dalam permintaan kesehatan untuk setiap individu menurun dan penurunan dalam permintaan perawatan kesehatan.

Tujuan dari Perilaku Hidup Bersih dan Sehat adalah untuk meningkatkan pengetahuan, kesadaran dan kemauan masyarakat agar hidup sehat, serta meningkatkan peran aktif masyarakat termasuk swasta dan dunia usaha, dalam upaya mewujudkan derajat hidup yang optimal (Dinkes, 2006).

Indikator PHBS Tatanan Rumah Tangga dalam tatanan rumah tangga, yang menjadi indikator PHBS adalah (Dinkes, 2006):

1. Pertolongan persalinan oleh tenaga kesehatan

2. Imunisasi dan penimbangan

3. Jamban keluarga

4. Air bersih

5. Penanganan sampah

6. Kebersihan kuku

7. Gizi keluarga

8. Kebiasaan merokok dan menyalahgunakan Napza

9. Informasi PMS/AIDS

10. JPKM/Dana sehat/Askes lainnya.

Indikator lingkungan menurut Dinkes (2006), dalam PHBS, meliputi:

1. Terdapat jamban, termasuk penggunaan dan pemeliharaanya

2. Terdapat air bersih dan pemanfaatan untuk kesehatan

3. Terdapat tempat sampah dan pengelolaannya

4. Terdapat saluran pembuangan air limbah dan pengelolaannya

5. Terdapat ventilasi

6. Kepadatan penghuni

7. Lantai bukan tanah

PHBS di tempat kerja merupakan upaya memberdayakan para pekerja agar tahu, mau dan mampu mempraktikkan PHBS serta berperan aktif dalam mewujudkan tempat kerja sehat. Penerapan PHBS di tempat kerja diperlukan untuk menjaga, memelihara dan mempertahankan kesehatan pekerja agar tetap sehat dan produktif (Dinkes, 2009).

Manfaat PHBS di tempat kerja diantaranya masyarakat di sekitar tempat kerja menjadi lebih sehat dan tidak mudah sakit, serta lingkungan di sekitar tempat kerja menjadi lebih bersih, indah dan sehat.

Berdasarkan latar belakang diatas dapat dirumuskan masalah penelitian sebagai berikut " Apakah terdapat korelasi antara pendidikan, pendapatan dan perilaku hidup bersih dan sehat para pedagang makanan di sekitar Universitas Pakuan Bogor. 


\section{METODOLOGI PENELITIAN}

Penelitian ini merupakan penelitian korelasional. Subjek penelitian adalah pedagang makanan di sekitar kampus Universitas Pakuan Bogor. Waktu penelitian dilakukan dari bulan November sampai dengan Januari 2015. Tempat penelitian dilakukan di sekitar kampus Universitas Pakuan Bogor. Populasi penelitian ini adalah pedagang makanan di sekitar kampus Universitas Pakuan Bogor. Analisis dalam penelitian ini adalah analisis bivariat, maka sampel yang digunakan minimal 30 sampel. Peneliti menetapkan sampel sebanyak 40 sampel. Data yang didapat akan dianalisis dengan uji regresi dan korelasi dengan SPSS 20. Teknik pengambilan sampel menggunakan metode survey, observasi dan wawancara. Variabel bebasnya adalah Pendidikan dan pendapatan pedagang makanan dan variabel terikatnya adalah Perilaku hidup bersih dan sehat (PHBS) para pedagang makanan di kawasan Unpak. Tingkat Pendidikan diukur dengan skala pengukuran kategorikal $0=$ tidak sekolah, $1=$ SD dan SMP, SMA dan PT $=2$. Pendapatan diukur dengan kategorial , 0 = di bawah UMR dan $1=$ di atas atau sama dengan UMR. Perilaku Hidup Bersih dan Sehat (PHBS) dengan menggunakan pedoman wawancara, dilakukan dengan wawancara dan pengamatan/observasi. Skala pengukuran: kategorikal, $0=$ kurang sehat dan $1=$ sehat . Sumber data dalam penelitian ini adalah data primer yang berasal dari wawancara dan pengamatan langsung dengan subjek penelitian dengan menggunakan kuesioner yang terstruktur. Pengolahan dan analisis data dengan menggunakan software komputer yaitu SPSS versi 20.

\section{HASIL PENELITIAN}

\section{Gambaran Umum Pedagang Makanan di Kawasan Unpak}

\section{a. Umur}

Hasil penelitian menunjukkan umur pedagang kaki lima rata - rata adalah 37 tahun dengan umur termuda 16 tahun dan umur tertua 70 tahun.

\section{b. Jenis Kelamin}

Tabel 1 Distribusi Pedagang Kaki Lima Berdasarkan Jenis Kelamin

\begin{tabular}{c|c}
\hline Jenis Kelamin & Persentase ( \%) \\
\hline Laki - laki & 77,5 \\
\hline Perempuan & 22,5 \\
\hline Total & 100 \\
\hline
\end{tabular}

Berdasarkan tabel diatas diketahui jenis kelamin pedagang makanan di kawasan Universitas Pakuan sebagian besar berjenis kelamin laki - laki 31 orang ( $77,5 \%$ ) dan perempuan hanya 9 orang ( 22,5 ).

\section{c. Lama Bekerja}

Hasil penelitian menunjukkan lama bekerja pedagang makanan di kawasan Universitas Pakuan rata - rata 9 tahun dengan lama bekerja terbaru adalah 2 bulan dan terlama adalah 40 tahun. Sampel yang diambil adalah pedagang makanan yang berjualan saat siang hari.

\section{d. Pendapatan para Pedagang Makanan}

Tabel 2 Pendapatan para Pedagang Makanan

\begin{tabular}{l|l}
\hline Variabel & Pendapatan/ bulan \\
\hline $\mathrm{N}$ & 40 \\
\hline Mean & Rp. 4.685 .750 \\
\hline SD & 473350.6 \\
\hline Median & Rp. 4.425 .000 \\
\hline Mak & Rp. 13.500 .000 \\
\hline Min & Rp. 1.500 .000 \\
\hline
\end{tabular}

Gambaran subjek penelitian berdasarkan pendapatan per bulan tertinggi adalah Rp. 13.500 .000 dan pendapatan terendah adalah Rp. 1.500 .000 per bulan. 


\section{e. Kondisi Lingkungan Pedagang Makanan}

Tabel 3 Kondisi Lingkungan Pedagang Makanan

\begin{tabular}{|c|c|c|c|}
\hline No & Kriteria & $\mathrm{F}$ & $\%$ \\
\hline \multirow[t]{4}{*}{1} & Lantai tempat berjualan & & \\
\hline & Keramik & 23 & 57,5 \\
\hline & Semen & 10 & 25 \\
\hline & Tanah & 7 & 17,5 \\
\hline \multirow[t]{4}{*}{2} & Dinding tempat berjualan & & \\
\hline & Tenda & 24 & 60 \\
\hline & Seng & 4 & 30 \\
\hline & Batu bata & 12 & 10 \\
\hline \multirow[t]{3}{*}{3} & WC & & \\
\hline & $<5 \mathrm{mtr}$ & 16 & 40 \\
\hline & $>5 \mathrm{mtr}$ & 24 & 60 \\
\hline \multirow[t]{3}{*}{4} & Tempat sampah & & \\
\hline & Ada & 31 & 77,5 \\
\hline & Tidak ada & 9 & 22,5 \\
\hline \multirow[t]{3}{*}{5} & Kondisi lantai saat hujan & & \\
\hline & Basah & 25 & 62,5 \\
\hline & Tidak basah & 15 & 37,5 \\
\hline \multirow[t]{3}{*}{6} & Pembuangan limbah & & \\
\hline & Ada & 26 & 65 \\
\hline & Tidak ada & 14 & 35 \\
\hline \multirow[t]{3}{*}{7} & Air PAM & & \\
\hline & Ada & 24 & 60 \\
\hline & Tidak ada & 16 & 40 \\
\hline \multicolumn{2}{|c|}{ Total } & 40 & 100 \\
\hline
\end{tabular}

\section{f. Korelasi Pendidikan dan Pendapatan dengan PHBS}

1) Pendidikan Pedagang Makanan

Berdasarkan hasil penelitian diperoleh adanya variasi tingkat pendidikan pedagang makanan di kawasan Universitas Pakuan. Menurut keputusan Menteri Pendidikan dan Kebudayaan No. 0306/V/ 1995, tentang pelaksanaan wajib belajar pendidikan dasar adalah 9 tahun, maka pendidikan responden dapat dikategorikan sebagai berikut :

Tabel 4 Tingkat Pendidikan Pedagang Makana

\begin{tabular}{lcc}
\hline Pendidikan & Frekuensi & $(\%)$ \\
\hline Tidak Sekolah & 0 & 0 \\
& & 2,5 \\
\hline SD & 1 & 20 \\
\hline SMP & 8 & 75 \\
\hline SMA & 30 & 2,5
\end{tabular}

a. Pendapatan Pedagang Makanan

Tabel 5 Tingkat Pendapatan Pedagang Makanan 


\begin{tabular}{lll}
\hline $\begin{array}{l}\text { Pendapatan } \\
\text { ( UMR : Rp. 1.750.000) }\end{array}$ & Frekuensi & Persentase (\% ) \\
& & \\
\hline Dibawah UMR & 11 & 27,5 \\
\hline Diatas UMR & 29 & 72,5 \\
\hline \multicolumn{1}{c}{ Total } & 40 & 100 \\
\hline
\end{tabular}

\section{2) Perilaku Hidup Bersih dan Sehat}

Gambaran perilaku hidup bersih dan sehat ( PHBS ) berdasarkan hasil wawancara diperoleh, skor minimal 10 dan skor maksimal 100. Setelah dikategorikan berdasarkan 15 pertanyaan perilaku yang meliputi 10 perilaku yang berkorelasi dengan kesehatan lingkungan dan 5 indikator lingkungan di tempat kerja menurut Dinkes ( 2009 ), maka perilaku sehat adalah $\geq$ 60 skor jawaban, $\mathrm{n}$ dan kurang sehat $<60$ skor jawaban. Kategori PHBS dapat dilihat pada tabel dibawah ini :

Tabel 6 Kategori tingkat Kesehatan

\begin{tabular}{lrc}
\hline PHBS & Frekuensi & Persentase \\
\hline Sehat & 32 & 80 \\
\hline $\begin{array}{l}\text { Kurang } \\
\text { Sehat }\end{array}$ & 8 & 20 \\
\hline
\end{tabular}

Dari tabel diatas menunjukka $80 \%$ pedagang makanan di kawasan Universitas Pakuan menunjukkan perilaku sehat, dan sekitar dari $20 \%$ berperilaku kurang sehat.

3) Korelasi antara pendidikan dengan perilaku hidup bersih dan sehat

Hipotesis pertama yang diajukan dalam penelitian ini adalah terdapat korelasi positif antara pendidikan $\left(\mathrm{X}_{1}\right)$ dengan perilaku hidup bersih dan sehat $(\mathrm{Y})$. Korelasi kedua variabel tersebut mempunyai persamaan regresi linier sederhana yaitu $: \hat{Y}=a+b x_{1}$. Perhitungan persamaan regresi $\mathrm{X}_{1}$ dan $\mathrm{Y}$ dapat dilihat pada tabel dibawah ini.

Tabel 7 Persamaan regresi $X_{1}$ dan $Y$

\begin{tabular}{|c|c|c|c|c|c|}
\hline \multirow[t]{2}{*}{ Model } & \multicolumn{2}{|c|}{$\begin{array}{l}\text { Unstandardized } \\
\text { Coefficients }\end{array}$} & \multirow[t]{2}{*}{$\begin{array}{l}\text { Standardize } \\
\mathrm{d} \\
\text { Coefficients } \\
\end{array}$} & \multirow[t]{2}{*}{$\mathrm{T}$} & \multirow[t]{2}{*}{ Sig. } \\
\hline & $B$ & Std. Error & & & \\
\hline Constant) & .222 & .086 & & 2.587 & .014 \\
\hline pendidikan & .746 & .098 & .77 & 7.641 & .000 \\
\hline
\end{tabular}

a. Dependent Variable: phbs

Dari perhitungan diperoleh angka 0,222 yang merupakan nilai a dan 0,746 adalah nilai b, maka analisis linier sederhana antara pengetahuan pencemaran dengan perilaku hidup bersih dan sehat memiliki persamaan regresi $\hat{Y}=0,222+0,746 X_{1}$.

Selanjutnya untuk mengetahui derajat keberartian ( signifikan) dilakukan menggunakan SPSS-20 dengan melihat tabel Anova. Hasil perhitungan keberartian persamaan regresi dapat dilihat pada tabel dibawah ini : 
Tabel 8 Signifikansi Persamaan regresi $X_{1}$ dan $Y$

\begin{tabular}{lllllll|}
\hline \multicolumn{1}{l}{ Model } & \multicolumn{1}{l}{ Sum } & of Df & & Mean Square & $F$ & Sig. \\
& Squares & & & & & \\
\hline Regression & 3.877 & 1 & 3.877 & 58.382 & $.000^{\mathrm{b}}$ \\
Residual & 2.523 & 38 & .066 & & \\
Total & 6.400 & 39 & & & \\
\hline
\end{tabular}

a. Dependent Variable: phbs

b. Predictors: (Constant), pendidikan

Dari data diperoleh nilai probabilitas (sig) adalah $0,000^{\mathrm{b}}$ yang berarti kurang dari 0,05 . Dengan demikian persamaan regresi $\hat{Y}=0,222+0,746 X_{1}$. dinyatakan signifikan. Pengujian mengenai keberartian hasil regresi tersebut, juga dimaksudkan untuk menguji hipotesis tentang adanya korelasi positif antara pendidikan $\left(\mathrm{X}_{1}\right)$ dengan perilaku hidup bersih dan sehatl $(\mathrm{Y})$.

Hipotesis yang menyatakan bahwa terdapat korelasi positif antara variabel pendidikan $\left(\mathrm{X}_{1}\right)$ dengan perilaku hidup bersih dan sehatl $(\mathrm{Y})$ diuji dengan analisis korelasi menggunakan SPSS-20. Hasil perhitungan analisis koefisien korelasi dapat dilihat pada tabel dibawah ini.

Tabel 9. Analisis Koefisien Korelasi

\begin{tabular}{|c|c|c|c|}
\hline & & Phbs & pendidikan \\
\hline \multirow{3}{*}{ Phbs } & Pearson Correlation & 1 & $.778^{* *}$ \\
\hline & tailed) & & .000 \\
\hline & $\begin{array}{c}\mathrm{N} \\
\text { Pearson Correlation }\end{array}$ & $\begin{array}{l}40 \\
.778^{* *}\end{array}$ & $\begin{array}{l}40 \\
1\end{array}$ \\
\hline Pendidikan & tailed) & .000 & \\
\hline & $\mathrm{N}$ & 40 & 40 \\
\hline
\end{tabular}

Perhitungan analisis regresi pada tabel diatas menghasilkan koefisien korelasi $r_{y 1}$ sebesar 0,778 pada $\alpha=0,01$, yang berarti hipotesis yang menyatakan bahwa terdapat ada korelasi antara pendidikan $\left(X_{1}\right)$ dengan perilaku hidup bersih dan sehat $(Y)$, artinya makin tinggi tingkat pendidikan, perilaku hidup bersih dan sehat juga tinggi. Koefisien determinan $\left(r^{2}{ }^{2}\right)$ sebesar 0,606 yang berarti faktor pendidikan berperan atau memberikan kontribusi sebesar 60,6 $\%$ terhadap perilaku hidup bersih dan sehat sedangkan 39,4 \% dipengaruhi oleh faktor lain.

4) Korelasi antara pendapatan dengan perilaku hidup bersih dan sehat

Hipotesis kedua yang diajukan dalam penelitian ini adalah terdapat korelasi positif antara pendapatan $\left(\mathrm{X}_{2}\right)$ dengan perilaku hidup bersih dan sehat $(\mathrm{Y})$. Korelasi kedua variabel tersebut mempunyai persamaan regresi linier sederhana yaitu $: \hat{Y}=a+b x_{1}$. Perhitungan persamaan regresi $X_{1}$ dan $Y$ dapat dilihat pada tabel dibawah ini.

Tabel 10 Persamaan regresi $\mathrm{X}_{2}$ dan $\mathrm{Y}$

\begin{tabular}{|c|c|c|c|c|c|}
\hline \multirow[t]{2}{*}{ Model } & \multicolumn{2}{|c|}{$\begin{array}{l}\text { Unstandardized } \\
\text { Coefficients }\end{array}$} & $\begin{array}{l}\text { Standa } \\
\text { rdized } \\
\text { Coefficients }\end{array}$ & $\mathrm{t}$ & $g$. \\
\hline & B & Error & Beta & & \\
\hline $\begin{array}{l}\text { (Constant) } \\
\text { pendapatan }\end{array}$ & $\begin{array}{l}.364 \\
.602\end{array}$ & $\begin{array}{l}.092 \\
.108\end{array}$ & .672 & $\begin{array}{l}3.968 \\
5.592\end{array}$ & $\begin{array}{l}.000 \\
.000 \\
\end{array}$ \\
\hline
\end{tabular}

a. Dependent Variable: phbs 
Dari perhitungan diperoleh angka 0,364 yang merupakan nilai a dan 0,602 adalah nilai $\mathrm{b}$, maka analisis linier sederhana antara pendapatan dengan perilaku hidup bersih dan sehat memiliki persamaan regresi $\hat{Y}=0,364+0,602 \mathrm{X}_{2}$.

Selanjutnya untuk mengetahui derajat keberartian ( signifikan) dilakukan menggunakan SPSS-20 dengan melihat tabel Anova. Hasil perhitungan keberartian persamaan regresi dapat dilihat pada tabel dibawah ini :

Tabel 11 Signifikansi Persamaan regresi $\mathrm{X}_{2}$ dan $\mathrm{Y}$

\begin{tabular}{|c|c|c|c|c|c|c|}
\hline Model & $\begin{array}{l}\text { Sum of } \\
\text { Squares }\end{array}$ & & Df & Square ${ }^{\text {Mean }}$ & $\mathrm{F}$ & Si \\
\hline Regression & 2.889 & & 1 & 2.889 & 31.269 & $.000^{\mathrm{b}}$ \\
\hline Residual & 3.511 & 18 & 3 & .092 & & \\
\hline Total & 6.400 & 9 & 3 & & & \\
\hline
\end{tabular}

a. Dependent Variable: phbs

b. Predictors: (Constant), pendapatan

Dari data diperoleh nilai probabilitas (sig) adalah $0,000^{\mathrm{b}}$ yang berarti kurang dari 0,05 . Dengan demikian persamaan regresi $\hat{Y}=0,364+0,602 X_{2}$ dinyatakan signifikan. Pengujian mengenai keberartian hasil regresi tersebut, juga dimaksudkan untuk menguji hipotesis tentang adanya korelasi positif antara pendapatan $\left(\mathrm{X}_{2}\right)$ dengan perilaku hidup bersih dan sehatl $(\mathrm{Y})$.

Hipotesis yang menyatakan bahwa terdapat korelasi positif antara variabel pendidikan $\left(\mathrm{X}_{1}\right)$ dengan perilaku hidup bersih dan sehatl $(\mathrm{Y})$ diuji dengan analisis korelasi menggunakan SPSS-20. Hasil perhitungan analisis koefisien korelasi dapat dilihat pada tabel dibawah ini.

\section{dengan $Y$}

Tabel 12 Analisis Koefisien Korelasi $X_{2}$

\begin{tabular}{|c|c|c|c|}
\hline & & phbs & Pendapatan \\
\hline & $\begin{array}{l}\text { Pearson } \\
\text { Correlation }\end{array}$ & 1 & $672^{* *}$ \\
\hline Phbs & $\begin{array}{l}\text { Sig. } \\
\text { tailed) }\end{array}$ & & .000 \\
\hline & $\mathrm{N}$ & 40 & 40 \\
\hline & $\begin{array}{l}\text { Pearson } \\
\text { Correlation }\end{array}$ & & 1 \\
\hline $\begin{array}{l}\text { Pendapat } \\
\text { an }\end{array}$ & $\begin{array}{l}\text { Sig. } \\
\text { tailed) }\end{array}$ & .000 & \\
\hline & $\mathrm{N}$ & 40 & 40 \\
\hline
\end{tabular}

level (2-tailed). 
Perhitungan analisis regresi pada tabel diatas menghasilkan koefisien korelasi $r_{\mathrm{y} 1}$ sebesar 0,672 pada $\alpha=0,01$, yang berarti hipotesis yang menyatakan bahwa terdapat korelasi positif antara pendapatan $\left(\mathrm{X}_{2}\right)$ dengan perilaku hidup bersih dan sehat $(\mathrm{Y})$, artinya makin tinggi tingkat pendapatan, tentu perilaku hidup bersih dan sehat juga tinggi. Koefisien determinan $\left(r^{2}{ }^{2}\right)$ sebesar 0,451 yang berarti faktor pendapatan berperan atau memberikan kontribusi sebesar $45,1 \%$ terhadap perilaku hidup bersih dan sehat sedangkan $64,9 \%$ dipengaruhi oleh faktor lain.

\section{PEMBAHASAN}

\section{Pendidikan Pedagang Makanan di Kawasan Unpak}

Berdasarkan hasil penelitian menunjukkan adanya variasi tingkat pendidikan pedagang Makanan di Kawasan Unpak. Menurut Keputusan Menteri Pendidikan dan Kebudayaan No.0306/V/1995, tentang pelaksanaan wajib belajar pendidikan dasar adalah 9 tahun, diperolah bahwa sebagian besar pedagang Makanan di Kawasan Unpak berpendidikan tinggi yaitu sebanyak 31 orang (77,5\%) dan yang berpendidikan dasar adalah 9 orang $(22,5 \%)$. Hal ini mempengaruhi kualitas PHBS karena pendidikan merupakan salah satu faktor yang berkorelasi erat dengan kualitas PHBS (Daud, 2000). Pendidikan yang rendah ini juga mempengaruhi tingkat wawasan mengenai sanitasi lingkungan (Sumiarto, 1993). Jenjang pendidikan pedagang Makanan di Kawasan Unpak memegang peranan penting dalam kesehatan masyarakat. Pendidikan pedagang makanan yang rendah menjadikan mereka sulit memahami akan pentingnya higyene perorangan dan sanitasi lingkungan untuk mencegah terjangkitnya penyakit menular. Dengan sulit memahami arti penting PHBS menyebabkan pedagang makanan tidak peduli terhadap upaya pencegahan penyakit menular (Sander, 2005).

Hal tersebut akan berbeda dengan pedagang makanan yang memiliki tingkat pendidikan lebih tinggi karena memiliki PHBS lebih baik. Hal ini sesuai dengan penelitian Goodman (2001), bahwa seseorang yang berpendidikan tinggi dapat lebih memelihara tingkat kesehatannya daripada seseorang yang berpendidikan lebih rendah. Orang yang berpendidikan lebih tinggi lebih mudah untuk menjaga kesehatan di lingkungannya.

\section{Pendapatan Pedagang makanan di Kawasan Unpak}

Pedagang makanan di kawasan Unpak memperoleh pendapatan perhari tertinggi yaitu Rp. 13.500.000 dan pendapatan terendah $\mathrm{Rp}$ 1.500.000. Pendapatan merupakan faktor yang berkorelasi dengan kualitas PHBS (Daud, 2000). Pendapatan pedagang makanan tergolong dalam kelompok masyarakat berpenghasilan cukup sehingga dapat terpenuhinya kebutuhan pokok dalam jumlah cukup. Hal ini juga menyebabkan pedagang makanan sudah memperhatikan PHBS karena pedagang makanan tidak hanya berorientasi dengan perbaikan penghasilan namun juga kualitas makanan tetap terjaga kebersihannya karena semakin bersih makanannya akan banyak mendatangkan pelanggan sehingga penghasilannya pun akan bertambah. Bila ditinjau dari faktor sosial ekonomi, maka pendapatan merupakan salah satu faktor yang mempengaruhi tingkat wawasan masyarakat mengenai kesehatan lingkungan.

\section{Perilaku Hidup Bersih dan Sehat}

PHBS pada pedagang makanan yang diperoleh dengan wawancara memperlihatkan bahwa pedagang makanan sebagian besar yaitu 32 orang $(80 \%)$ berperilaku hidup bersih dan sehat dan hanya 8 orang $(20 \%)$ yang kurang berperilaku hidup bersih dan sehat. Perilaku pedagang makanan yang kurang sehat, berdasarkan hasil wawancara yaitu batuk tanpa menutup dengan tangan, meludah atau membuang dahak dilantai, tidak mengganti air cucian setelah digunakan lebih dari 10 kali, dan membuang air limbah di sembarang tempat. Perilaku yang termasuk kategori sehat ditunjukkan oleh pedagang yang telah melakukan tindakan meliputi menutup tangan bila batuk, tidak meludah atau membuang dahak dilantai, menggunakan air PAM untuk membuat makanan atau minuman, menggunakan air matang untuk membuat minuman, membuang sampah di tempat pembuangan sampah, membuang air limbah di tempat yang semestinya dan membiasakan mencuci tangan sebelum membuat atau menghidangkan panganan.

\section{Korelasi antara Pendidikan dengan Perilaku Hidup Bersih dan Sehat}

Analisis linier sederhana antara pengetahuan pencemaran dengan perilaku hidup bersih dan sehat memiliki persamaan regresi $\hat{Y}=0,222+0,746 X_{1}$. Dari data diperoleh nilai probabilitas (sig) adalah $0,000^{\mathrm{b}}$ yang berarti kurang dari 0,05 . Dengan demikian persamaan regresi $\hat{Y}=0,222+0,746 X_{1}$. 
dinyatakan signifikan. Pengujian mengenai keberartian hasil regresi tersebut, juga dimaksudkan untuk menguji hipotesis tentang adanya korelasi positif antara pendidikan $\left(\mathrm{X}_{1}\right)$ dengan perilaku hidup bersih dan sehatl $(Y)$.

Hipotesis yang menyatakan bahwa terdapat korelasi positif antara variabel pendidikan $\left(\mathrm{X}_{1}\right)$ dengan perilaku hidup bersih dan sehatl (Y) diuji dengan analisis korelasi menggunakan SPSS-20. Perhitungan analisis regresi menghasilkan koefisien korelasi $r_{y 1}$ sebesar 0,778 pada $\alpha=0,01$, yang berarti hipotesis yang menyatakan bahwa terdapat ada korelasi antara pendidikan $\left(\mathrm{X}_{1}\right)$ dengan perilaku hidup bersih dan sehat $(Y)$, artinya makin tinggi tingkat pendidikan, perilaku hidup bersih dan sehat juga tinggi. Koefisien determinan $\left(\mathrm{r}^{2} \mathrm{y} 1\right)$ sebesar 0,606 yang berarti faktor pendidikan berperan atau memberikan kontribusi sebesar 60,6 \% terhadap perilaku hidup bersih dan sehat sedangkan 39,4 \% dipengaruhi oleh faktor lain.

Tingkat pendidikan pedagang makanan sangat berpengaruh terhadap perubahan sikap menuju perilaku hidup bersih dan sehat. Tingkat pendidikan pedagang makanan yang rendah akan mempengaruhi pedagang dalam memperoleh dan mencerna informasi untuk kemudian menentukan pilihan dalam menerapkan hidup sehat. Hasil penelitian ini konsisten dengan penelitian Imanda (2009) yang menyimpulkan bahwa jenjang pendidikan memegang peranan penting dalam kesehatan masyarakat. Pendidikan masyarakat yang rendah menjadikan pedagang makanan sulit memahami akan arti pentingnya higyene perorangan dan sanitasi lingkungan untuk mencegah terjangkitnya penyakit menular. Penelitian ini juga sesuai dengan hasil penelitian Hardiyanto (2003), bahwa tingkat pendidikan yang kurang mendukung merupakan salah satu penyebab rendahnya kesadaran kesehatan lingkungan, karena kesadaran memerlukan pemahaman yang baik akan arti pentingnya kondisi lingkungan yang sehat. Semakin baik tingkat pendidikan formal, maka semakin baik pengetahuan tentang kesehatan, sehingga akan mematangkan pemahaman tentang pengetahuan kesehatan lingkungan dan kesadaran menjaga kesehatan lingkungan termasuk penerapan prinsip-prinsip hidup sehat. Selain tingkat pendidikan ada beberapa faktor yang mempengaruhi PHBS adalah pengetahuan, niat, motivasi, sarana, prasarana dan fasilitas juga social budaya. Menurut data wawancara tambahan, perilaku hidup bersih dan sehat para penjual makanan dikawasan Universitas Pakuan banyak dipengaruhi oleh sarana, prasarana dan fasilitas. Para pedagang makanan yang dijadikan sampel penelitian sebagian menjajakan makanannya hanya di tenda dan diatas tanah sehingga berpeluang untuk terpaparnya debu/ kotoran dari asap kendaraan yang lewat sehingga mengakibatkan infeksi saluran pernapasan. Walaupun sudah banyak pedagang yang sudah mengemasnya/ menutupnya dengan baik sehingga dapat meminimalisir debu dan lalat.

\section{Korelasi Pendapatan dengan Perilaku Hidup Bersih dan Sehat}

Dari perhitungan diperoleh angka 0,364 yang merupakan nilai a dan 0,602 adalah nilai b, maka analisis linier sederhana antara pendapatan dengan perilaku hidup bersih dan sehat memiliki persamaan regresi $\hat{Y}=0,364+0,602 X_{2}$. Dari data diperoleh nilai probabilitas (sig) adalah $0,000^{\mathrm{b}}$ yang berarti kurang dari 0,05 . Dengan demikian persamaan regresi $\hat{Y}=0,364+0,602 X_{2}$ dinyatakan signifikan. Pengujian mengenai keberartian hasil regresi tersebut, juga dimaksudkan untuk menguji hipotesis tentang adanya korelasi positif antara pendapatan $\left(\mathrm{X}_{2}\right)$ dengan perilaku hidup bersih dan sehatl $(\mathrm{Y})$.

Hipotesis yang menyatakan bahwa terdapat korelasi positif antara variabel pendidikan $\left(\mathrm{X}_{1}\right)$ dengan perilaku hidup bersih dan sehatl (Y) diuji dengan analisis korelasi menggunakan SPSS-20. Perhitungan analisis regresi menghasilkan koefisien korelasi $r_{y 2}$ sebesar 0,672 pada $\alpha=0,01$, yang berarti hipotesis yang menyatakan bahwa terdapat korelasi positif antara pendapatan $\left(\mathrm{X}_{2}\right)$ dengan perilaku hidup bersih dan sehat $(\mathrm{Y})$, artinya makin tinggi tingkat pendapatan, tentu perilaku hidup bersih dan sehat juga tinggi. Koefisien determinan $\left(r^{2} y 2\right)$ sebesar 0,451 yang berarti faktor pendapatan berperan atau memberikan kontribusi sebesar $45,1 \%$ terhadap perilaku hidup bersih dan sehat sedangkan $64,9 \%$ dipengaruhi oleh faktor lain.

Tingkat pendapatan pedagang makanan sangat berpengaruh terhadap perubahan sikap menuju perilaku hidup bersih dan sehat. Tingkat pendapatan pedagang makanan yang rendah akan mempengaruhi pedagang makanan dalam memperoleh dan mencerna informasi untuk kemudian menentukan pilihan dalam menerapkan hidup sehat. Pedagang makanan yang belum dapat mencukupi kebutuhan sehari-hari juga mengakibatkan pedagang makanan lebih berorientasi pada pemenuhan kebutuhan hidup daripada pengobatan penyakit dan pencegahan penyakit berupa PHBS baik di rumah maupun di tempat kerja. Pedagang makanan di kawasan Unpak memperoleh pendapatan perbulan tertinggi yaitu Rp. 13.500.000 dan pendapatan terendah Rp 1.500.000. Pendapatan merupakan faktor yang berkorelasi dengan kualitas PHBS (Daud, 2000). Pendapatan pedagang makanan tergolong dalam kelompok masyarakat berpenghasilan cukup karena 72,5\% sudah berpenghasilan diatas UMR sehingga cukup terpenuhinya kebutuhan pokok sehari hari. Hal ini juga menyebabkan pedagang makanan sudah memperhatikan PHBS karena dengan menjaga dagangan tetap bersih dan sehat akan mendatangkan banyak pembeli/ konsumen karena sebagian besar konsumen adalah akademisi yang ada di Universitas Pakuan yang lebih cermat dalam memilih jajanan yang sehat. Bila ditinjau dari faktor sosial ekonomi, 
maka pendapatan merupakan salah satu faktor yang mempengaruhi tingkat wawasan masyarakat mengenai kesehatan lingkungan. Hal ini juga sesuai dengan penelitian yang dilakukan oleh Imanda 2009 bahwa tingkat pendapatan berkaitan dengan kemiskinan yang berpengaruh pada status kesehatan. Pendapatan merupakan salah satu faktor yang mempengaruhi tingkat wawasan masyarakat mengenai sanitasi lingkungan.

\section{SIMPULAN}

Berdasarkan hasil penelitian dan pembahasan di atas, maka dapat disimpulkan bahwa terdapat korelasi yang positif antara pendidikan dan pendapatan dengan perilaku hidup bersih dan sehat para pedagang makanan dikawasan universitas pakuan.

\section{DAFTAR PUSTAKA}

Amalia Imanda. 2009. Hubungan antara Pendidikan dengan Perilaku Hidup Bersih dan Sehat Pedagang HIK di Pasar Klowon Kota Surakarta. Surakarta : UMS

Budihardja. 2004. Perilaku Hidup Sehat Masyarakat Kurang. http://suara merdeka.com/harian/0310/02/kot18.htm. Semarang: Diakses tanggal 14 Maret 2009.

Daud, R. 2009. Hubungan Antara Tingkat Pendidikan, Pendapatan Dan Perilaku Masyarakat Dengan Kualitas Sanitasi Lingkungan Di Pesisir Pantai Desa Huangobotu Kecamatan Kabila Kabupaten Gorontalo. [Tesis] Yogyakarta: UGM.

Depkes RI. 1999. Rencana Pembangunan Kesehatan Menuju Indonesia Sehat 2015. Jakarta: Depkes RI. 2009. Panduan Manajemen PHBS Menuju Kabupaten/Kota Sehat. Tersedia dalam: http:// www.depkes.go.id Diakses tanggal 17 Juli 2009.

Dinkes. 2006. Pedoman Program Pembinaan Perilaku Hidup Bersih dan Sehat Tatanan Rumah Tangga. Bogor: Dinas Kesehatan Jawa Barat.

Goodman, A. 2001. The Economics of Health And Health Care. Third edition. New Jersey: Upper Saddle River.

Hardiyanto. 2003. Rendah Kesadaran Kesehatan Lingkungan. Tersedia dalam: http://suaramerdeka.com/hrian/0305/25/kol3.htm.

Machfoed. 2005. Perilaku Sehat Dalam Prinsip-prinsip Kesehatan. Yogyakarta: UGM.

Murti, B. 2005. The Family As Health Producer in Indonesia: A An Examination Using The Grossman Model And Its Extension. [Disertation] Australia: University of Newcastle.

Nasrul, M. 2007. Korelasi Antara Tingkat Pendidikan, Pendapatan dan Perilaku Hidup Bersih dan Sehat Pada Masyarakat Kecamatan Sangir Kabupaten Solok. [Skripsi] Yogyakarta: UGM.

2006. Desain dan Ukuran Sampel Untuk Penelitian Kuantitatif dan Kualitatif di Bidang Kesehatan. Yogyakarta: Gadjah Mada University Press.

Notoatmodjo, S. 2003. Ilmu Kesehatan Masyarakat. Jakarta: PT. Rineka Cipta. 2005. Promosi Kesehatan Teori dan Aplikasi. Jakarta: PT. Rineka Cipta.

2005. Pengantar Pendidikan Kesehatan dan IImu Perilaku Kesehatan. Yogyakarta: Andi Offset.

Sander M.A. 2005. Hubungan Faktor Sosio Budaya Dengan Kejadian Diare di Desa Candinegoro Kecamatan Wonoayu Sidoarjo. Jurnal Medikal. Vol 2. No.2. Juli-Desember 2005: 163-193.

Simons-Morton B.G., Greene, W.H. and Gottlieb, N.H. 1995. Introduction to Health Education and Health Promotion. Second edition. Waveland Press, Inc. Illinois, USA.

WHO. 1992. Pendidikan Kesehatan (terjemahan). Bandung: ITB Press.

Widoyono. 2008. Penyakit Tropis: Epidemiologi, Penularan, Pencegahan, dan Pemberantasannya. Semarang: Penerbit Erlangga.

Widyastuti P (ed). 2005. Epidemiologi Suatu Pengantar. Edisi 2. Jakarta: EGC.

Zaahara, T. 2000. Upaya Peningkatan Perilaku Hidup Sehat Dalam Keluarga Dalam Rangka Pembangunan Keluarga Sejahtera. http://www. Depdiknas.go.id/jurnal/30/upaya peningkatan_perilaku_hidup.htm. Jakarta. 